\title{
Cognitive Structure of Beliefs and Habits: How to Challenge Them?
}

\author{
Tanise Knakievicz \\ Postgraduate Program in Education, UNIOESTE, Foz do Iguaçu, Brazil \\ Email: tanise.knakievicz@gmail.com
}

Received 29 November 2015; accepted 14 December 2015; published 18 December 2015

Copyright (C) 2015 by author and OALib.

This work is licensed under the Creative Commons Attribution International License (CC BY). http://creativecommons.org/licenses/by/4.0/

(c) (i) Open Access

\section{Abstract}

This paper studies the cognitive structure of beliefs and its associated habits and suggests techniques for the identification and recycling of these, through the prism of the consciential paradigm. To do this, it first describes the role of conscientiometry and social interaction in self-knowledge. Secondly, it differentiates naïve interactions from the empathic ones. And, in third place, it brings a scheme of conceptual maps to show the complex interassistential actions and interactions contained in the recycling processes, as well as some reflections on the peer interaction, interassistentialy and consciential recycling.

\section{Keywords}

\section{Platypus Consciential Syndrome, Beliefs, Fear of Rejection, Resentment, Consciential Recycling, Thosenic Rehabilitation}

\section{Subject Areas: Education}

\section{Introduction}

In Greek mythology, Sisyphus was considered the shrewdest of all mortals. Master of malice, wit and fun, deceived the gods, but to get to Tartarus received an exemplary punishment of the gods for his great rebellion. He was condemned for all eternity to roll a large marble stone to the summit of a mountain which, then, through an irresistible force, rolled down the mountain to the starting point again, invalidating all the effort repeatedly.

If we consider the characters of this myth, different egos of a same consciousness, it's possible to interpret that the excess of thoughtless actions can result in much expenditure of effort in an area of personal manifestation. In the case of a workaholic person, the daily actions set invisible habits of impulsiveness and competitiveness in the thosenity. This habit may even bring some success and intraphysical achievements at a point, but at the cost of making the consciousness a prisoner of the illusion that there's no choice of action, in special, in some manifestation area of least resistance locus, by way thosenes (Table 1) more useful. Believing to be 
Table 1. Summary of the conscientiology neologism [2] used in this study.

\begin{tabular}{|c|c|}
\hline Neologism & Definition and description \\
\hline Conscienciotherapy & $\begin{array}{l}\text { The area of Conscientiology applied to the study of therapy or treatment, relief and remission of } \\
\text { distrúbios of consciousness. Conscientiotherapy use of resources and techniques derived from the } \\
\text { "internal" consciousness approach for the pathologies and parapathologies. }\end{array}$ \\
\hline Conscientiometry & $\begin{array}{l}\text { The area of Conscientiology applied to studies and reseach of set rules for the metric, measures the } \\
\text { condition, function or quality of "internal” consciousness capable of establishing the possible bases } \\
\text { of matermatização of consciousness, for example, through conscientiogram. }\end{array}$ \\
\hline Cosmoethics & $\begin{array}{l}\text { The area of Conscientiology applied to the study and research of ethics or reflection on the cosmic } \\
\text { moral, multidimensional, setting the consciousness holomaturity, located beyond social, } \\
\text { intraphysical morality, or that presented in any human label, discernment so most moral and } \\
\text { emotional, from the micro-universe intimacy of each consciousness(cosmo + ethics). }\end{array}$ \\
\hline Groupalkarmic interprisons & $\begin{array}{l}\text { The coercive interconsciential commitment arising from joint anticosmoethical actions or in groups, } \\
\text { the inseparability groupkarmic condition of the evolutionary consciousness principle or conscience. }\end{array}$ \\
\hline Penta & $\begin{array}{l}\text { An individual assistential transmission of energy programmed for a certain hour in the day of the } \\
\text { individual, directed by one or more non-physical helpers (personal energetic task). It is performed } \\
\text { while in the waking state and is directed to ill or deficient non-physical consciousnesses and } \\
\text { projected persons who are intangible and invisible to common human vision. Personal energetic } \\
\text { task used by Dr. Vieira-in his approximately half-century of psychic experiences. }\end{array}$ \\
\hline Polykarmality & $\begin{array}{l}\text { The most evolved condition of holokarmology, beyond egocarmalidade and groupkarmality, when } \\
\text { consciousness focuses on interconsciential lucid assistance of way spontaneously, cosmoethical and } \\
\text { intense your point in this venture the raison d'être of evolution itsel. }\end{array}$ \\
\hline Robéxis & $\begin{array}{l}\text { The quality, condition or state of puppet of the tropospheric intraphysical consciousness without } \\
\text { freedom of action, too enslaved to geoenergia, intraphysicality or tetradimensionality. }\end{array}$ \\
\hline Self-unforgiveness & $\begin{array}{l}\text { The self-unforgiveness consciousness is the man or woman consciousness, at the level of } \\
\text { self-discipline and self-conscientiality unable to forgive themselves about the mistakes, errors and } \\
\text { omissions, in order to eliminate, ultimately, the aware self-corruptions. }\end{array}$ \\
\hline Self-unforgiveness & $\begin{array}{l}\text { The self-unforgiveness consciousness is the man or woman consciousness, at the level of } \\
\text { self-discipline and self-conscientiality unable to forgive themselves about the mistakes, errors and } \\
\text { omissions, in order to eliminate, ultimately, the aware self-corruptions. }\end{array}$ \\
\hline Seriexological & $\begin{array}{l}\text { The study area of the multiexistential evolutionary condition of the vital principle in human lives, or } \\
\text { intraphysicality, through the Genetic, sums, mesologias, and multiple consecutive societies. }\end{array}$ \\
\hline Thosene & $\begin{array}{l}\text { The unity of practical manifestation of consciousness, according to Conscientiology, considering } \\
\text { thought or idea (design), feeling or emotion, and energy consciential in inseparable way }\end{array}$ \\
\hline Thosenic & $\begin{array}{l}\text { The quality or set of thosenes (thoughts, feelings and energy) of a consciousness or consciousness } \\
\text { group. }\end{array}$ \\
\hline
\end{tabular}

powerless of imposing itself against the automation of neurophysiological routines, the consciousness may feel punished and victimized, what maintains the consciousness subdued in its own useless routines or compulsive behaviors.

Habits once identified can be modified by the use of techniques; however, the diagnosis is similar to the task of an archeologist [1]. There are very old and ingrained habits in the personal expression, which become difficult to perceive spontaneously by the consciousness itself. To observe the behaviors and emotions in social interactions is very useful, because they can reflect the consciousness reality, at least in part, enabling the selfresearcher to know the aspects of yourself through members of his familiar or affinity groups. In this manuscript, for the study of the cognitive structure of beliefs and its associated habits, I investigated myself intraconscientiality through theoretical and experimental framework of the consciential paradigm.

The simple action of looking at yourself and at others, carefully, serves genuine human needs of being perceived. To watch, see and look promotes the rescue and protection of the human self from one of its greatest pains, the pain of rejection and abandonment, and also creates a prophylaxis against resentment. I consider as second greatest human fear, after the fear of death, the fear of rejection. To feel noticed (perceived and understood) is the prophylaxis of rejection and resentment [3]. "Interassistentiality is the experience of interconsciential, mutual assistance, based specially on the re-education through the clarification task (tares), the evolutive 
intelligence (EI), the cosmoethics, the polykarmality (Table 1) and in the cosmic principle of the less sick helps the sicker" [4].

Interassistenciality starts at self-assistenciality [2] and by self-assessment through conscientiometry (Table 1) [5]. One of the goals of conscientiometry is to identify evolutionary skills of the consciousness and to establish a scheduled education for the multidimensional, pluriexistential and multissecular evolution of its thosenity [6].

The response of the 2000 questions of the Conscientiogram [5] plotted in a $360^{\circ}$ chart outlines an approach to the consciousness reality, which is being used as a reference for the early diagnosis of operative beliefs in the consciential microuniverse and to the seriexological study of the author (Figure 1).

The highly asymmetric chart pattern may reflect thosenic habits that prioritize some consciential attributes and neglect others, and also can predict about the expressed intraconsciential conflicts, latent or about the nature or quality of the growing crises of the consciousness under review in this article. One aspect of the intraphysical social interaction is the instinctive expectation that the behavior of the participants resembles the average standard of the group, and so people with similar thosenity tend to cluster [7]. When dissonant behavior is acknowledged, even these being cosmoethical and rationally logical, they can be felt as emotionally dysfunctional [8] [9].

Human behavior can be influenced by companies, through the neuronal mirror [10] [11]. Thus, in the recycling of a behavior, choosing to be with people who are committed to similar goals promotes mutual and reciprocal support among those people, because they naturally feel integrated to do things in order to cooperate or compete, adding efforts for the group's goal, which can be influenced by charismatic people. To observe and question the motives of charismatic and communicative people as to the exemplarism of their self-recycling and to apply preventive techniques of sympathetic deassimilation, is an act of self-respect and caution regarding the influences of thoughtless behavior. Personal conduct, even under the influence of mirror neurons, is a very personal responsibility [2].

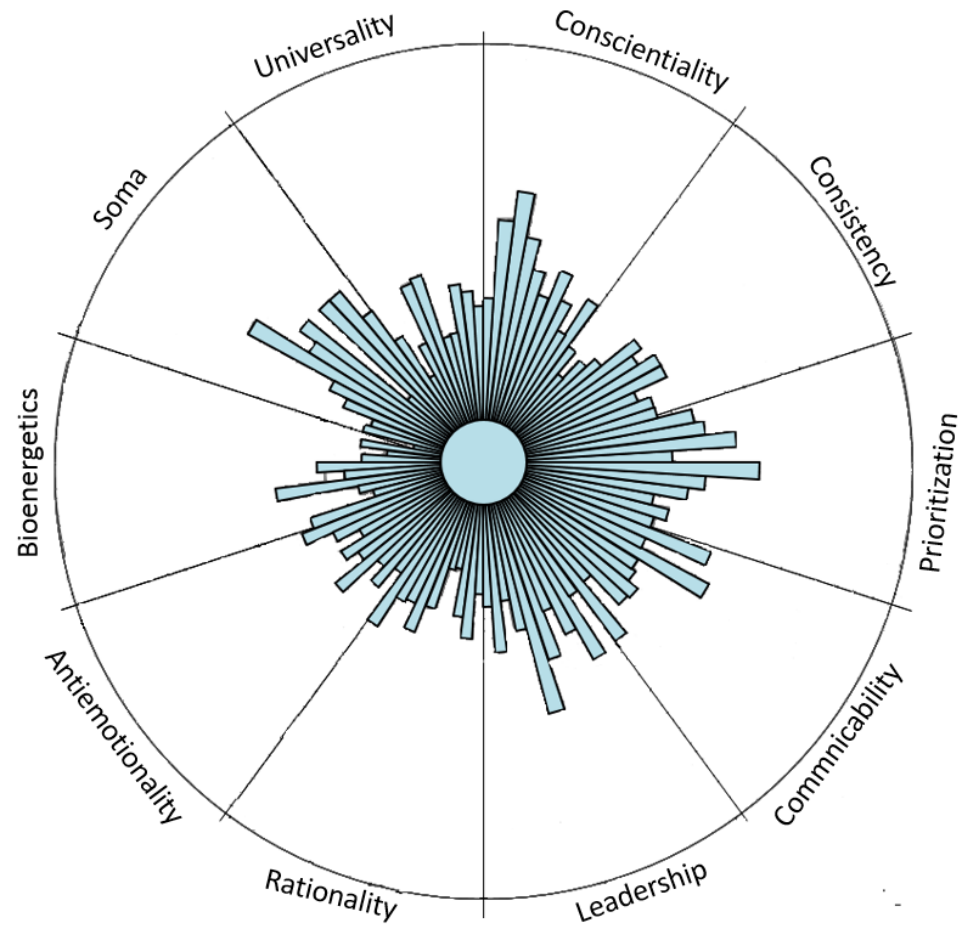

Figure 1. $360^{\circ}$ Conscientiometric graph of the T. Knakievicz self-research. The graphic reveals a marked asymmetry between consciential attributes located on the left of the graph (rationality, anti-emotionality, bioenergetics, soma and universalism) in relation to the attributes in the right (conscientiality, coherence, prioritization, communicability and leadership). In 2008 and 2009 were applied 3 previous questionnaires to acknowledgement and selfcalibration of the assessment tool, obtaining similar results this graph from 2011. 
Behaving in different ways may reverberate in the group as an act of rejection, so the prevention to this emotional sensation comes from the habit of conscious reflection about the personal and the group's thosenity. Through self-knowledge, the intraphysical consciousness perceives its role as a minicog in the groups it participates. The minicog sees itself as an assistant in its positive aspects and as assisted in the weak traits of its consciential manifestation. The commitment to recycling personal thosenic patterns contributes indirectly to the whole karmic group, to which the consciousness is interconnected by its intellectual affinities and affective bonding. Thereby, recycling demands energetic self-control to maintain the personal thosenic pattern and to generate the recycling of the counterflow resulted from the average standard of its group.

\section{Habits \& Beliefs}

Broad sense belief is a pervasive attitude in the process of human knowledge that considers something as true and relevant, regardless the certainty or prolonged reflection of experimentation [12]. Beliefs reflect o understanding one has of the world and orients its behavior [1]. The beliefs are a small plateau in consciential evolution [6], and at a certain point has to be recycled, modified or abandoned. When the consciousness does not know itself deeply, it may confuse its integrity with the ones of its beliefs and behaviors, and so the process of change takes dramatic tones, because it feels as if its self or its own life were under threat, and it is in these cases where the autonomous and instinctive parts of the brain comes into action, for it is their natural function to maintain the biological integrity of the soma [13]. So, the stronger the emotion, the greater the attachment of narrowed attention on what is most disturbing [14].

Therefore, under adverse conditions, or under constant and diffuse stress, the brain is an efficient machine to generate beliefs. Once formed the beliefs, regardless if these are true or false, the brain selects the evidences that confirm it, ignoring the information that belie them. Confirmation of beliefs increases the sense of security and emotional confidence. Therefore, the more positive the evidences (even if biased by selected filters), more enhanced is the belief, in such a way that it can become an unquestionable truth [15]. So doubting one's own beliefs is an opportunity to understand how the brain's neurobiology operates and to understand its operating mechanisms, as well as to know the intimacy of one's own conscientiality. According to Shermer, we build our beliefs by several different subjective, personal, emotional and psychological reasons, in contexts created by family, friends, colleagues, culture and society. Once consolidated these beliefs, we defend them, we justify with a profusion of intellectual reasons, convincing arguments and rational explanations. First come the beliefs and then the explanations [15].

One of the greatest human suffering are the uncertainties about the future and the fear of death, and these anxieties feed a powerful reptilian cerebral system, pervasive and lasting creator of beliefs that support the attachment and dependence on dogmatic cultural traditionalism. However, democratic societies have allowed space to people's freedom of thought, for example, even in the omnipresence of religious sentiment, atheists have brought to light the reflection of their opinions. The debates promoted by critics of atheists publications have increased credits for the use of public space of reason, removing religions and religious beliefs from the taboo condition [12].

Also according to Shermer, the change of belief occurs more often in science, but not as often as one might expect given the idealized image of the worshiped "scientific methods", for which only facts matter. But scientists are human beings, subject to any of the vagaries of emotion and the influence of cognitive shifts when mold and reinforce their beliefs [15]. Is it possible to live without beliefs? The experimentation of the disbelief principle and of the habit of self-observation can provide the necessary consciential attributes in the search of information so that the consciousness can manifest itself free from beliefs in any dimension in which it may be [16].

\subsection{Types of Habit Changes}

Habits, even though automatic and invisible, are not inevitable. They can be discovered by observation techniques and then modified, eliminated and/or newly created [1]. The habit changes can be classified according to the focus of the recycling action, from simples changes in the neuromuscular routines, such as the acquisition of physical conditioning to complex changes of thosenic rehabilitation, such as the change of personal temperament.

\subsubsection{Neuromuscular Changes}

Implement routines of maintenance of healthy physical conditioning, learn to write or drive a car are examples 
of acquisition of relatively simple habits.

\subsubsection{Changes in Body Language}

The body posture when reacting to the stimuli of life are also automated, and can generate groupalkarmicinterprisons (Table 1) because of the invisible conditionings and its consequences (in) preventable. The reactions can be reactive or active, impulsive or reflexive and are manifested by tics, gestures or body movements [1]. Postural education can be enhanced through the knowledge of rules of social etiquette and body language [17] [18].

\subsubsection{Emotional Change}

The focus of attention of the intraphysical consciousness in its emotional reactions and its associated sentiments. Individual or group therapy contribute to the understanding of emotional routines (physiological sensations) and their respective feelings (interpretation of emotions). The emotional pain monopolizes the attention of the consciousness at that point, and the more it victimizes itself, more increases the pain, the greater the pain, the greater the focus of attention given to it, in a futile and painful vicious cycle. Breaking this pathological cycle and liberating cognitive space for the recycling of thosenic habits occurs through therapeutic, psychosomatic and energetic techniques such as these listed below:

a) The Emotional Freedom Technique (EFT): developed in the 90s in the United States by Gary Craig, from the simplification of the complex techniques of Dr. Roger Callaghan. Its curative principle relies on the restoration of the energetic flow in the meridians of the body [19].

b) The Eye Movement Desensitization and Reprocessing Technique (EMDR): developed in the United States in the 80 s by the psychologist Francine Shapiro, encourages reprocessing difficult and painful memories in different brain hemispheres [20].

c) The Microphysiotherapy: a technique that identifies the primary cause of a disease or symptom and stimulates the body's self-healing, developed in France in 1983 by the physical therapists and osteopaths Daniel Grosjean and Patrice Benini [21].

In short, these techniques of emotional recycling cushion the emotional pain of the impact that may occur from the refutation of some beliefs, allowing the consciousness to relax and observe other angles of its own reality, in many cases, that is enough for its self-healing. Other times, these techniques allow the establishment of inner calm, mentalsomatic serenity for the coupling with the helpers, the diagnosis identification and the selection of the most appropriate therapy and absorption of ectoplasm [22]. These and other psychosomatic therapeutic techniques are useful in recycling thosenic habits structured from invisible beliefs and their dysfunctional and anachronistic behavior.

\subsubsection{Cognitive Change}

New information can change the whole interpretation of the facts. For example: 1) retrocognition on the view over life scenarios, of social interactions and of spirituality beyond the grave; 2) the acquisition of the habit of gratitude ceases the flow of self-victimizations; 3) and the application of the disbelief principle promotes the understanding of the difference between the trusting, skeptical and scientific positions. Believing or not believing in something, are two sides of the same coin. "Belief is mental laziness for many people" [6].

From these concepts, a series of emotional and behavioral habits can become dysfunctional and anachronistic. Due to intercorrelations between habits, one associated to others, such as pieces of a puzzle. The general adjustment of these pieces reveals the temperament of the consciousness. By changing up a piece, or a small habit, there are repercussions in several other habits and in the intimate harmony of the consciousness, that is, its temperament is oscillating and undefined.

As well as the first specimen of stuffed platypus taken to England classified by the scientific community as a scam by the set of its atypical characteristics, one also can be perceived by itself and others as a scam, hoax and weird. This interval between feeling adjusted and simultaneously unadjusted can be defined as the platypus consciousness syndrome, these features can help the consciousness in this critical period:

a) Cosmoethics Personal Code-CPC: faced with inner conflicts arising from the change of habits, the CPC is a prophylactic feature of intra and interpersonal conflicts, available to all [2].

b) Vibrational State-VS or EV (from Portuguese's Estado Vibracional): it's the key to homeostatic consciential recycling because it harmonizes the holosomatic vibration pattern, preventing emotional disorders and physical ailments. It is the technical condition of maximum dynamization of the energosoma's energies, beyond the 
slow vibrations of the soma, through the impulsion of the will [2]. The EV is a technique of energetic sympathetic deassimilation.

\section{Eating Habits and the Predisposition to Beliefs}

One of the basic and indispensable habits to intraphysical human life is feeding. There are healthy eating habits and anti-physiological others that cause diseases, for example, the intake of indigestible, allergenic or toxic food. Some research suggests that the excessive consumption of carbohydrates generates ideological and/or religious fanaticism [23] [24]. According to Perlmutter and Loberg, carbohydrates put fire in the brain through the sugar spikes in the blood, setting off an inflammatory cascade effect in the brain and altering the production of insulin by the pancreas [25].

The pancreas is responsible for the synthesis of the principal digestive enzymes of the gut, and is a major source of extra neuronal dopamine in the body [26]. Pancreatic dopamine acts locally in the gut and participates in the modulation of insulin, serotonin and dopamine release in pancreatic cells by modulating changes in energy availability, with important implications to the energetic homeostasis [27] [28].

Wheat grains, rye and barley, and other members of the grasses, contain proteins difficult to digest by humans because it requires specific digestive enzymes that are missing to most people [29]. Then, the partial digestion of the gluten proteins in the intestine releases peptides similar to morphine, these gluten exorphin induce the dependence of wheat [25] [29] and the production of immunogenic peptides with crossed response to the nervous tissue [30]. Gluten is considered the smoking of today, for it changes the brain chemistry, interfering with the brain reward center, with several side effects such as migraine, epilepsy, schizophrenia, irregular distribution of blood in the brain, progressive neurological disorders and irreversible damage in cases of continuous intake [25] [29].

The increase in neuronal dopamine levels is naturally triggered by endogenous mechanisms, through phenylethylamine signaling produced from physical activity, or when you're in love, or through phenethylamines by eating foods such as chocolate and grains that have this alkaloid [31]. The Mayans and Aztecs believed that cocoa was the food of the gods, for it gave them wisdom and universal knowledge [32]. In the Christian culture, the wheat is the sacred food [33] and added chocolate to the festivities of religious traditions such as Christmas and Easter [32]. Similar to the endogenous phenylethylamine and food phenethylamines, there are the amphetamines used as medicines or drugs, unlike phenylethylamine and phenethylamines, it remains in high concentration in the organisms by long time. Both exogenous phenethylamines as the amphetamines may have significant impact on behavior motivated by the reward [31] [34].

Dopamine played a decisive role in neuronal development of behavior motivated by reward and mediates environmental and social interaction of all animal groups. The neuronal dopamine is associated with creativity, schizophrenia, learning, belief, passion and violence [15] [35]. The pancreatic dopamine participates in the homeostasis of energetic balance via regulation of the levels of insulin and glucagon, protection of the intestinal mucosa while maintaining the epithelial impermeability [36]. Dopamine binds the adaptative neurophysiology of environmental and social interaction to learning processes, even though its performance being instinctive and organic, may have some link to the psychosomatic wounds, via robotization habits or robéxis (Table 1). Therefore, knowing the neurophysiology of human learning can contribute to the prevention, treatment of emotional scars and/or facilitate recycling simple intraphysicalhabits, such as those of eating.

\section{Halo Effect in the Change of a Habit}

By recycling a habit, the associated habits hitherto invisible can become evident, first, as a figure in subtle relief in an uniform color surface, and with the maintenance of data collection from self-research, in a second moment, the colors in crisp and flashy shades become so evident that is hard to conceive that were just unnoticed.

The newly perceived habits as coherent to the desired values and principles, provide an increase in selfesteem. For example, the habit of being punctual commitments to cooperate in implementing the target value of being a responsible professional. But if invisible behavioral habits are inconsistent and incoherent as the new desired values, generate growth crisis. For example, person who has a habit of being distracted paying attention to randomly and freely all stimulus, when they wish to be responsible, will have to face an invisible enemy, the dispersion habit, especially not if they not self notice dispersed.

This is a major bottleneck phase of adaptation to new social and cultural contexts. Through self-research the individual may self notice that to be responsible, they must first acquire the ability to prioritize the attention and 
focus on each task that performs at every moment, i.e. unlearn the dispersion of habit. There are those who kick to the previous level of self-knowledge, in the absence of self-motivation for the search for self-knowledge and self-research, then, they could become self-victimized, and they could abdicate of your autonomy and responsibility to take refuge in the cognitive structure of dogmatic cultures, to find the comfort of a mythological explanation for their instinctive behaviors and actions. And there are others who choose to make use of the scientific cognitive structure to overcome conflicts, thus seeking support to improve by the means of physiology, psychiatry, psychology, group dynamics, parapsychic dynamics, conscientiometry and conscientiotherapy (Table 1).

Facing this bottleneck, the consciousness acquire information about itself, in order to get closer to the cosmovision of its own consciential reality. This panoramic knowledge is the beginning of the comprehension of evolutive intelligence. The continuous recycling of small habits and the acquisition of new homeostatic attributes result in the holosomatic homeostasis of a new evolutionary level, consolidated by temperament change.

The experience of extrapolation phenomena is similar to a test drive of the experience of what would be to have the desired homeostatic temperament. Such experiences are promoted by helping consciousnesses that are engaged in the processes of intraconsciential reurbanization through energetic baths [2], contributing for the identification by the recycler with new useful, functional and homeostatic thosenic patterns. Personal evolution is very personal, for it is the result of prioritizations and behavioral choices related to one's own motivation, independently of the context.

\section{Peer Interaction}

Regarding the happiness and well-being, the most important thing in people's lives is their social network, in which only one or two actual connections already show significant psychological and physical benefits. Social interaction promotes the synthesis of neurotransmitters that trigger responses to inhibit physiological stress responses, relaxation and wellness, encouraging compassionate behavior [31]. The recognition and gratitude to these social connections creates happiness and well-being [37].

In particular, it was found that friendships built in religious congregations are what make people happier than theology or spirituality [38]. Therefore, the person aware that her brain can be influenced all the time by various means, even without notice, avoids impulsive decision making. Knowing neurophysiology and having the ability to discern can contribute to the prophylaxis of ingenuity and consciential manipulations [35], resulting from impulsivity, thoughtlessness and reactivity commons in people with anxious temperaments (Figure 2).

Vanity and ingenuity is seen as a lack of empathy. People with low empathy do not interact with each other, have glazed eyes, see in the other a reflection of themselves. Do not relate effectively with reality and do not relate effectively with others, seeing the world the way they want and do not take into consideration the reality of the facts and other people. These are owners of the truth people, with great self-confidence in their convictions, purity of feelings and do not change their minds [39].

One of the consequences of naïve people is to be guided by sympathy and not by the verification of the intent in acts. When confronted with the consequence of their actions, their emotions come into play and their judgment is based on the outcome of the action, not in the intention [15]. Although the loss of naivety, through experiences, is not an unscathed process it occurs gradually by empathic and lucid social interactions. Consciential evolution is processed in the way that the emotional sores are processed too, metabolized and cleared rationally, such as the method of manufacturing the oysters by pearls (Figure 3).

There are several psychotherapeutic and energotherapeutic techniques available to help maintain the energetic balance necessary for the psychosoma to handle with this transient disruption of homeostasis, which naturally occurs on the breakdown and elimination of old beliefs. In the anticipation of recycling, new insights, facts and data are previously collected to replace the void left the removal of an old belief, preventing the inert input of a similar thosenical structure [40].

I have a hypothesis that many of the clinical cases of mental and physical illnesses, depending on the locus of lower consciousness resistance, result from challenged and refuted beliefs, in unconscious level, disorganizing the thosenical pattern of the consciousness in this process of change. Physical illness can be interpreted as an expression of lack of vibrational harmony between the holosoma's vehicles. The VS (Vibrational State) allows the consciousness to adjust the holosoma to the its new thosenical pattern, recycling old stale emotional, neuromuscular or eating habits throught the adequate self-attention and self-assistance needed to the establishment of the new level of consciential homeostasis. 


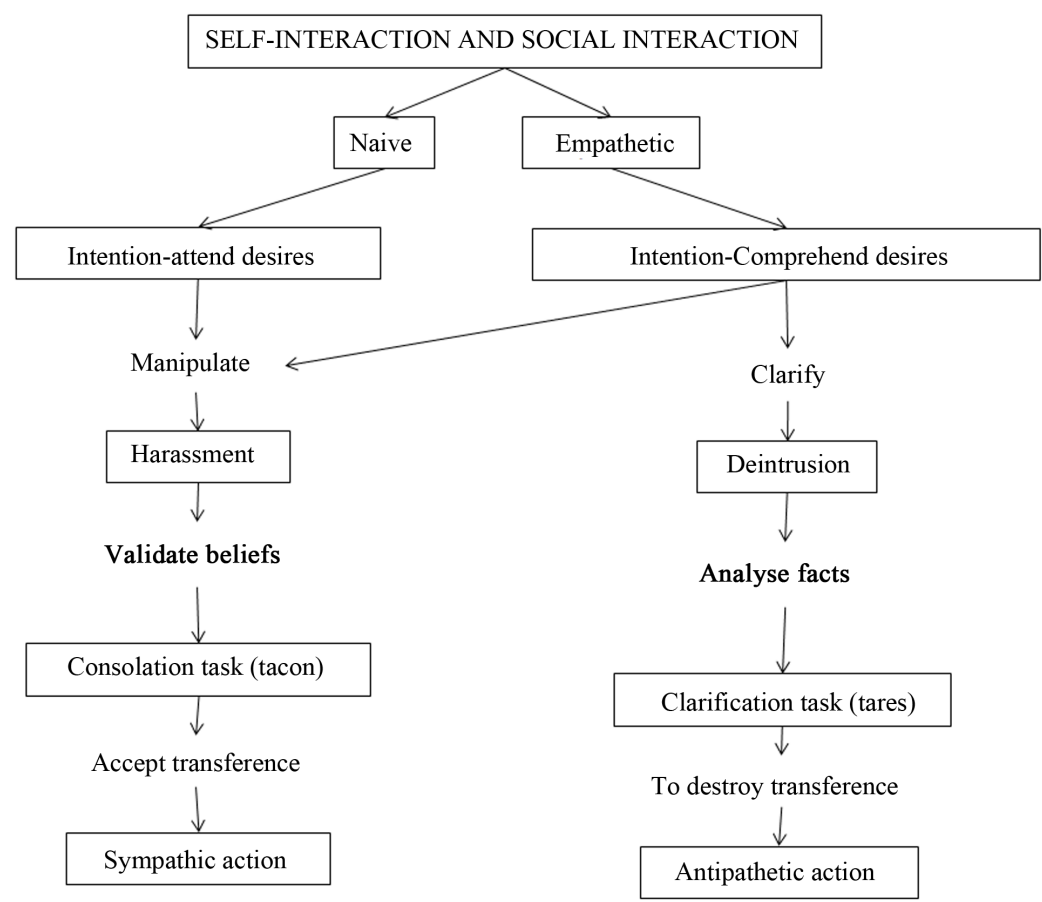

Figure 2. Conceptual map of self and social interactions. Self-interaction: refers to the person's level of interaction with itself, with its own different egos, social roles, dreams and desires. Social interaction: refers to the person's level of interaction with other people in its circle of social relations. Naïve interaction is the one established from few facts and parafacts (superficial). Empathic interaction is the one established from the knowledge of many facts and parafacts (deep). By accepting transferences one assumes the responsibility of solving the ills and sorrows of each other. By destroying the transference, one denies the role of savior of the other, removing the other from the role of passive victim facing its reality. The most important in social interactions, whether sympathetic or antipathetic, is the identification of the motivations, if unethical or cosmoethical, that is, if the results aimed at increasing consciential dependency or autonomy.

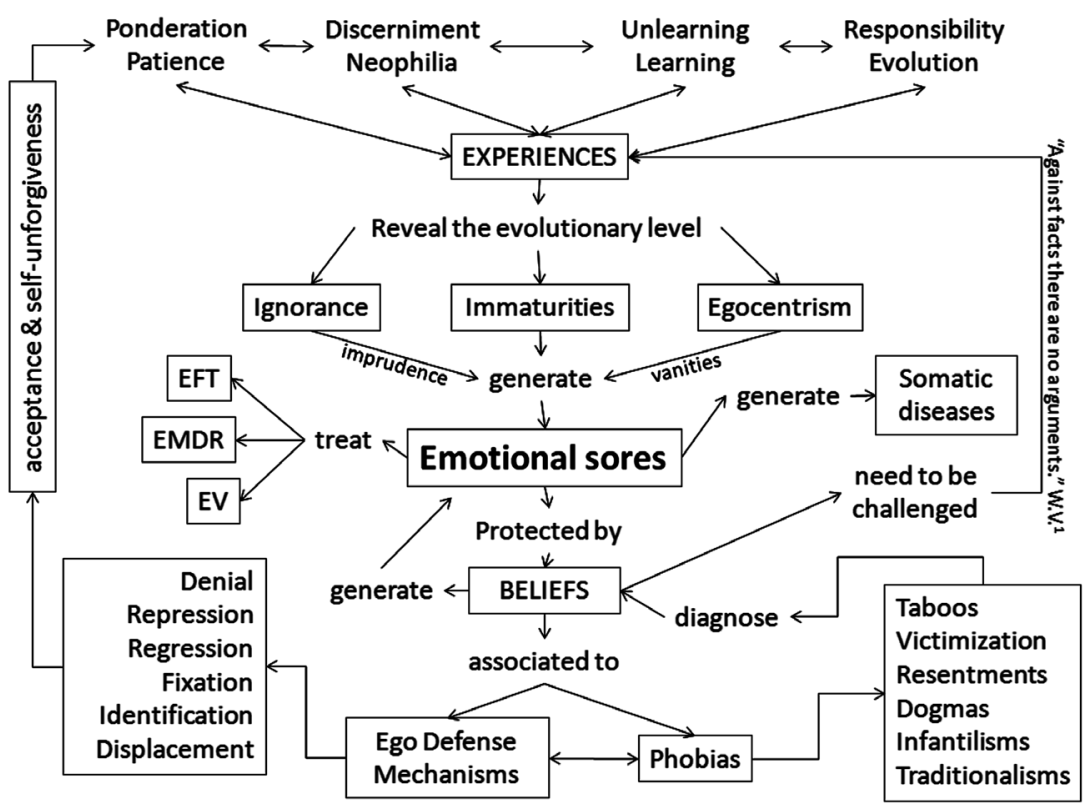

Figure 3. Conceptual map of the processing of transformation of emotional sores in consciential virtues. Beliefs are structured from the weakest or conscientially pathological points, thus defying them takes courage to adjust the focus to see what hitherto was refused to be looked at, through the collection of experiences and analysis of each situation, then beliefs are challenged. ${ }^{1}$ Waldo Vieira. 


\section{Interassistentialy \& Consciential Recycling}

Frequently, present in charismatic social interactions, compliments and undeserved praise can help people to have a distorted and unrealistic image about themselves and share expectations from skills they do not possess. Such idealizations both create discomfort in those who receive such praise, as well as envy and resentment in those are not perceived, but genuinely has consciousness of having the skills highlighted in the other. To report these distortions of perceptions in social life is a way of contributing to the development of a more coherent personal and social metrics. The analysis of information collected from self-evaluation and hetero-evaluations on the concepts of what is failure and what success is, under personal parameters and under the average social parameters in which each group operates, contributed to the identification of mechanisms triggering self-corruptions, envy, resentment, and associated motivational needs, as well as sources of orientation, motivation and inspiration for the necessary self-recycling.

According to Nietzsche, resentment is the reaction of a desire for an imaginary revenge in order to obtain a repair not an action, in other words, the instinctive and unthinking, misunderstood reaction [41]. Resentment refers to a constellation of negative emotions-anger, envy, vengeful ruminations, bitterness. Resentment is an insistent, repetitive complaint, which does not accept any form of retaliation. What characterizes the resentment is the persistence of grief, the repetition of the complaint [42].

The self-perception of being a slave of external stimuli, where action is nothing but emotional reaction may hurt the pride of those who see themselves as rational and self-centered people. Resentment, then, comes from the self-made choice of self-victimizing and promotes the search of foreign culprits for personal disabilities. The resentful consciousnesses are not weak, naïve, honest nor correct, it is vain and choose the shelters, the subterfuges, ego defense mechanisms, because everything that is hidden, obscure, pleases them. There is a link between envy and resentment [42]. Thus, resentful people, usually are very intelligent, worship intelligence, create and/or are mythological geniuses in various areas of knowledge, for example Isaac Newton [43]. And these myths help the resentful to justify their conception of what is bad from the basic concept that being good is equivalent to being themselves [41].

The resentful is that person who deliberately rejects some aspects of himself, refuses to accept self-responsibility for his shortcomings and deficiencies, and assumes the role of victim, electing someone or some context as executioner, which somehow reflect what the resentful despises in himself and aims to forget, and creates a savior, or a saving situation to be found in the end of a rainbow, through heroic actions. Such heroic actions can be found in the biographies of Galileo Galilei, Isaac Newton and Gregor Mendel [43]-[45]. When these actions have egoic and anticosmoethical motivations they create complex groupalkarmicinterprisions, while the cosmoethical aspects can create clarity and self-esteem contributions needed to the overcoming of self-resentment.

Sustaining self-forgiveness requires the primary forgetting of the cause of pain and for this, the consciousness seeks to defend what it already knows, but does not accepted by vanity, through different ego defense mechanisms [46]. Ego defense mechanisms are used by the consciousness so that something unacceptable it not selfperceived and perceived by others. When a group has such psychological contract [47], its members cooperate mutually in order not to be integrally perceived, establishing a pseudosocial way of living. Paradoxically, to be invisible inside of the group, feeds the resentment back. The current cultural industry promotes the incredibly violent display of such resented relationships in the form of a shocking audio-visual stimulation and on a global scale, satisfying the desire of the resentful viewers [3] [42].

Dealing face to face with failures, however painful they may be, promotes self-acceptance. Thus, unlike self-forgiveness, self-acceptance of one's consciential reality prepares the person to face the perceived flaws and shortcomings, serving as a useful and benign alternative to promote well-being. Self-acceptance is not self-forgiveness, but is inherently unconditional [48]. As well as the fear of biological death is overcome by the experience of lucid projectability and retrocognitions, the fear of rejection and resentment is overcome by the theorice experimentation of self-acceptance (Figure 4).

Self-acceptance also increases the willingness to work and improve the areas in which we present major deficiencies. The reflected self-acceptance is the basis of the self-unforgiveness (Table 1) and hetero-forgiveness posture which is based on the sense of cosmoethics dignity [49] [50]. The theoriced self-consciencialization of the inner value of every being, intra and extraphysical, sustains the sense of cosmoethic dignity, which manifests itself in respectful words and actions directed at oneself and towards others. 


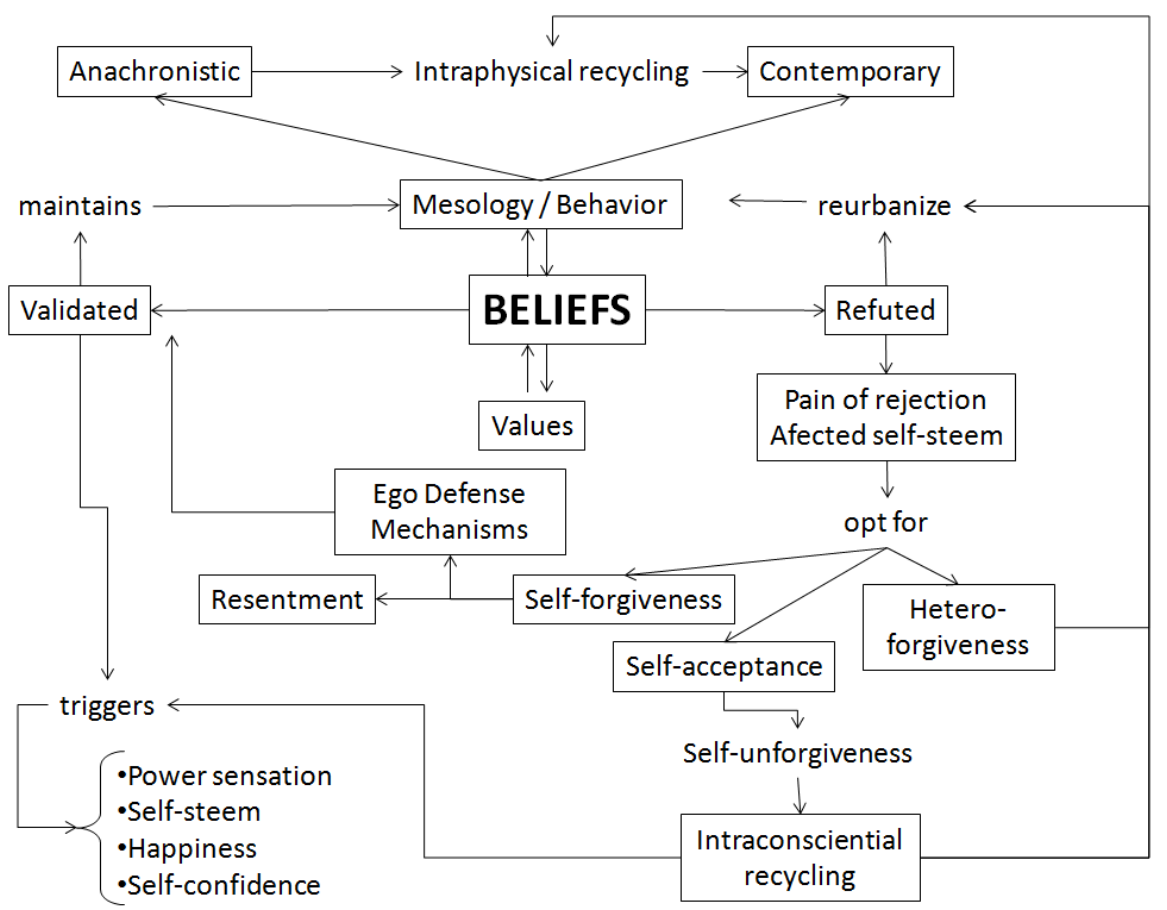

Figure 4. Conceptual map of intraconsciential recycling. Beliefs validated or refuted trigger feelings of well-being and best value in people and social groups, but by different psychological processes and result in different social balances, i.e. traditionalism or social innovations.

Kindness, the quality of being benign and not presenting dangerous character, is part of the temperament of lucid and interassistential consciousnesses [2] [4]-[6] [16]. These lucid consciousness process personal mistakes without any self-forgiveness, and treat all misconceptions of others with hetero-forgiveness and competent interconsciential assistance [2]. It was found that, in people who have become more compassionate by training, there was a consequent increase in the inferior parietal cortex activity, in the dorsolateral prefrontal cortex and in the nucleus accumbens, brain regions involved in the regulation of empathy, comprehension and other positive emotions.

According to Vieira [4], the technique of anticonflictuosity-self-pacification is the process of depuration of actions, gestural, verbal and graphic communication, intentions and thosenes conducted by pre-serene consciousnesses, ex-warmongering, prioritizing the elimination of personal and hetero-conflicts and the implementation of inner pacification, taking the example of Homo sapiens pacificus.

Forgetting the new and recently learned is not always repression [51]. Learning and adapting to new contexts, is dependent on the ability to transfer a lesson from one situation to another, for a time required to train and fix new habits in the intraphysical brain. Therefore, this transference disposition is universally present in all humans, and it is through it that interassistentiality occurs among peers.

The transference and countertransference are typical ways of the therapeutic relationship projection between assisted and assistant, and can be characterized positively, with feelings of affection and admiration, or negative, with feelings of aggression and resistance, depending on the unconscious and emotional bonding that emerge in this relation [51], promoted by reciprocal energetic interfusions and thosenic assimilations [2]. The transference relates to the emotional reactions of the assisted directed to the assistant, while the countertransference involves the thosenity of the assistant in relation to the assisted. The prevention of these processes is made by the technique of energetic sympathetic deassimilation [2]. The transference, countertransference and energetic assimilation mechanisms are inherent in the interassistential processes of exchanging knowledge and ectoplasm necessary for the destructuration of beliefs and for the healing processes [22].

Transferences in the process itself are inherent to the neurophysiology of human behavior by neuronal mirroring [10], and pathological transferences must be destroyed every time they are perceived to avoid refeeding victimization [51]. Once destroyed the actual figures of transference, others will emerge from what remains, un- 
til the consciousness learn to have autonomy in its evolutionary process and does not depend on its peers, in other words, until it overcomes its immaturities and egocentrisms (Figure 5).

The vibrational state self-nurtures the consciousness of the basic energetic elements necessary for learning the acquisition of energetic self-suficiency, and generates energy reserves available to homeostatic donations and interassistencial exchanges. "To evolve is to facilitate the difficult life in any dimension" [16].

\section{Conclusions and Inquires}

Conscienciometric self-assessment prevents resentments by self-attending the genuine need of every consciousness to feel noticed.

The recycling of simple habits optimizes the perception of complex and invisible habits, so far. How important is personal responsibility in the recycling of thosenical habits? The process of recycling habits can unchain the consciential platypus syndrome, which refers to inconsistencies in holosomatic manifestation. In what way instinctive and or anachronistic habits can be recycled with gentiliza, harmony, elegance, balance and finesse to avoid causing emotional wounds? What way?

The neurophysiology of belief correlates the neurophysiological processes of learning, creativity and schizophrenia. As this knowledge may help in understanding the paraphysiology and treatment of emotional wounds caused by the fear of rejection? The current cultural traditionalism meets everyday demands or it is reflexes of the traumas in previous lives? The understanding of seriexiality could contribute to improving the quality of life of the people?

Cognitive psychotherapies and energosomatic techniques are important resources to consciential reeducation, as they provide the basis for sustaining mentalsomatic actions. The conscientiogram, the cosmoethics personal code, the sense of cosmoethic dignity, the disbelief principle, the vibrational state, the habit of gratitude and the penta (Table 1) are resources available for those interested in qualifying intra and interassistential relations. "To evolve, strictly speaking is to educate yourself educating others” [6].

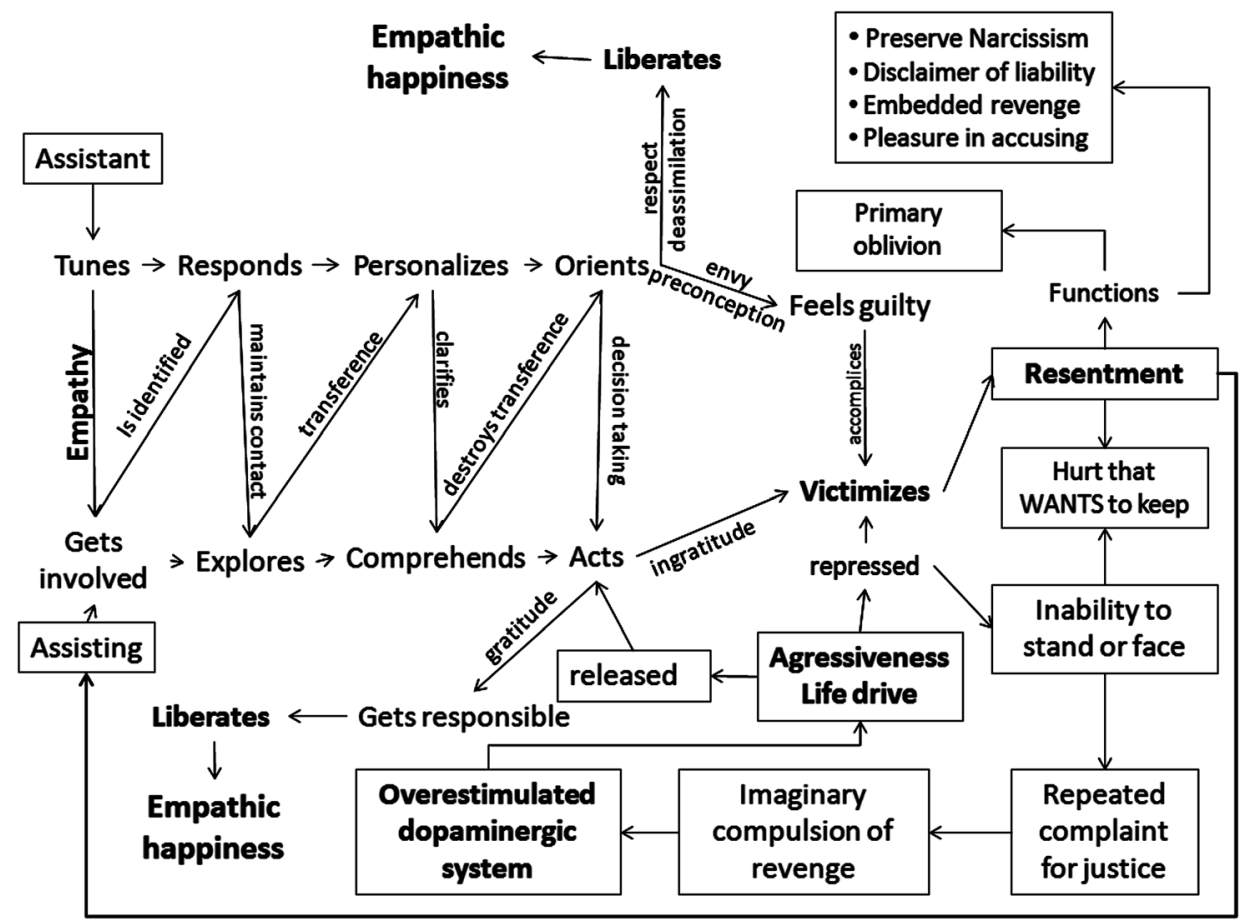

Figure 5. Interactions between assistant and assisted in reclicagem interassistencial. The respectful interactions among people allows successive cycles of interactions between related pairs, which intercalate themselves in the roles of assisted and assistant, as the skills and expertise required for the solution of the conflict in question. The healing and prophylactic elements of this interassistential system are gratitude and the vibrational state technique (EV). Adaptations from [35] [42] [48] [52]. 


\section{Acknowledgements}

I thank the therapists of the International Organization of Conscientiotherapy (OIC), the holistic therapist Doralice Gomes and the cognitive family therapist Ana Maria dos Remédios, Dr. Mariana Cabral Schveitzer and Dr. Tamara Cardoso André for contributions. My thanks to Stricto Sensu Graduate Program in Education-Area of Concentration of Science, Languages, Technology and Culture of the UNIOESTE, Foz do Iguaçu, and National program of CAPES Postdoctoral. I thank Laura Bruna Araújo for translation of the manuscript.

\section{References}

[1] Duhigg, C. (2012) O Poder do Hábito. Porquefazemos o quefazemosnavida e nos Negócios (The Power of Habit). Tradução de Rafael Mantovani. Objetiva, Rio de Janeiro.

[2] Vieira, W. (2014) Dicionário de Neologismos da Conscienciologia. Organizadora Lourdes Pinheiro. Editate, Foz do Iguaçu, 66, 109, 148, 185, 263, 264, 312, 368, 480, 488, 664, 679, 689, 852.

[3] Zuin, A. (2008) Aeducação de sísifo: Sobreressentimento, vingança e amok entre professores e alunos. Educação \& Sociedade, 29, 583-606. http://www.scielo.br/scielo.php?script=sci_arttext\&pid=S0101-73302008000200014 http://dx.doi.org/10.1590/S0101-73302008000200014

[4] Vieira, W. (2012) Enciclopédia da Conscienciologia. Foz do Iguaçu: AssociaçãoInternacional do Centro de Altos Estudos da Conscienciologia (CEAEC) e Associação Internacional Editares, 4983.

[5] Vieira, W. (1996) Conscienciometria: Técnica de avaliação da Consciência Integral (Conscientiometry: Valuation technique of Integral Consciousness). InstitutoInternacional de Projeciologia, Rio de Janeiro.

[6] Vieira, W. (1994) 700 Experimentos da Conscienciologia. InstitutoInternacional de Projeciologia, Rio de Janeiro, 67, 172, 380, 470.

[7] Schutz, W.C. (1989) Profunda Simplicidade-Uma nova consciência do eu interior. (Profound Simplicity).Ágora, São Paulo.

[8] Capiola, A. and Raudenbush, B. (2012) The Effects of Food Neophobia and Food Neophilia on Diet and Metabolic Processing. Food and Nutrition Sciences, 3, 1397-1403. http://dx.doi.org/10.4236/fns.2012.310183

[9] Moscovici, F. (2013) Desenvolvimento Interpessoal: Treinamentoemgrupo. 22nd Edition, José Olympio, Rio de Janeiro.

[10] Carter, R. (2012) O Livro do Cérebro (The human brain book). Tradução Frances Jones. Agir, Rio de Janeiro, 120.

[11] Vitale, J. (2006) O Manual de Instruçõesquevocêdeveriater Recebidoao Nascer (Life’s Missing Instruction Manual: The Guidebook You Should Have Been Given at First). Tradução Savannah Hartman, Landscape, São Paulo, 65.

[12] Luz, M. (2011) Onde a Religião Termina? Editares, Foz do Iguaçu.

[13] Luskin, F.E. and Pelletier, K.R. (2008) Acabe de Vez com o Estresse (Stress Free for Good). Tradução Maria Cristina Araújo, Francis, São Paulo.

[14] Goleman, D. (2014) Foco: A Atenção e seu Papel Fundamental para o Sucesso (Focus). Tradução Cássia Zanon, Objetiva, Rio de Janeiro.

[15] Shermer, M. (2012) The Cérebro \& Crença. De Fantasmas e Deuses à Política e às Conspirações—Como Nosso Cérebro Constrói Nossas Crenças e as Transformaem Verdades (The Believing Brain: The Believing Brain: From Ghosts and Gods to Politics and Conspiracies-How We Construct Beliefs and Reinforce Them as Truths). Tradução Eliana Rocha, JSN Editora, São Paulo, 21-22.

[16] Vieira, W. (2010) Enciclopédia da Concienciologia. Associação Internacional Editares, Brasil, 3067, 5704.

[17] Berckhan, B. (2013) A Arte de se Fazer Respeitar: Maneiras Inteligentes de Expressarseus Desejos e Estabelecer Limites (The Art of Gaining Respect). Tradução Carlos Nougué, Sextante, Rio de Janeiro.

[18] Pease, A. and Pease, B. (2013) A Linguagem Corporal no Trabalho: Como Causaruma Boa Impressão e se Destacarna Carreira (The Body Language in the Workplace). Tradução Andrea Holcberg, Sextante, Rio de Janeiro.

[19] Suh, J.W., Chung, S.Y., Kim, S.Y., Lee, J.H. and Kim, J.W. (2015) Anxiety and Anger Symptoms in Hwabyung Patients Improved More Following 4 Weeks of the Emotional Freedom Technique Program Compared to the Progressive Muscle Relaxation Program: A Randomized Controlled Trial. Evidence-Based Complementary and Alternative Medicine, 1, 1-9. http://www.ncbi.nlm.nih.gov/pmc/articles/PMC4619925/pdf/ECAM2015-203612.pdf

[20] Posmontier, B., Dovydaitis, T. and Lipman, K. (2010) Sexual Violence: Psychiatric Healing with Eye Movement Reprocessing and Desensitization. Health Care Women International, 31, 755-768. http://www.ncbi.nlm.nih.gov/pmc/articles/PMC3125707/pdf/nihms-295567.pdf http://dx.doi.org/10.1080/07399331003725523 
[21] Pereira, A.P., Carvalho, E.M.S., Kerppers, I.I.K., Furmann, M., et al. (2014) Assessment of Heart Rate Variability in Fibromyalgia after Micro-Physiotherapy. Manual Therapy, Posturology \& Rehabilitation Journal, 12, 191-195. http://www.mtprehabjournal.com/files/v12nx/v12a32.pdf http://dx.doi.org/10.17784/mtprehabjournal.2014.12.189

[22] Rossi, D. (2011) Ectoplasmy and Interassistantial Relations. Conscientia, 15, 567-576. http://www.ceaec.org/index.php/conscientia/article/view/495

[23] Callegaro, J.N. (2008) Mentecriativa: Aaventura do cérebrobemnutrido. Vozes, Petrópolis, RJ.

[24] Póvoa, H. (2002) O cérebrodesconhecido. Como o sistemadisgetivoafeta as emoções, regulanossaimunidade e funcionacomo um órgãointeligente. Objetiva, Rio de Janeiro.

[25] Perlmutter, D. and Loberg, K. (2014) A dieta da Mente: A surpreendenteverdadesobre o Glúten e oscarboidratosOsassassinossilenciosos do seucérebro (Grain Brain: The Surprising Truth about Wheat, Carbs, and Sugar-Your Brain’s Silent Killers). Tradução André Fontenelle, Paralela, São Paulo, 73-95.

[26] Mezey, E., Eisenhofer, G., Harta, G., Hansson, S., Gould, L., Hunyady, B. and Hoffman, B.J. (1996) A Novel Nonneuronal Catecholaminergic System: Exocrine Pancreas Synthesizes and Releases Dopamine. Proceedings of the National Academy of Sciences of the United States of America, 93, 10377-10382.

http://www.pnas.org/content/93/19/10377.full.pdf http://dx.doi.org/10.1073/pnas.93.19.10377

[27] Ohta, Y., Kosaka, Y., Kishimoto, N., Wang, J., et al. (2011) Convergence of the Insulin and Serotonin Programs in the Pancreatic $\beta$-Cell. Diabetes, 60, 3208-3216. http://diabetes.diabetesjournals.org/content/60/12/3208.full http://dx.doi.org/10.2337/db10-1192

[28] Vázquez, P., Robles, A.M., Pablo, F. and Hernández-Sánchez, C. (2014) Non-Neural Tyrosine Hydroxylase, via Modulation of Endocrine Pancreatic Precursors, Is Required for Normal Development of Beta Cells in the Mouse Pancreas. Diabetologia, 57, 2339-2347. http://www.ncbi.nlm.nih.gov/pmc/articles/PMC4181516/ http://dx.doi.org/10.1007/s00125-014-3341-6

[29] Braly, J. and Hoggan, R. (2014) O perigo do Glúten (Why Gluten Cereal Grains May Be Hazardous to Your Health). Tradução de Rosane Albert, Alaúde, São Paulo, 49-176.

[30] Alaedini, A., Okamoto, H., Briani, C., Wollenberg, K., Shill, H.A., Bushara, K.O., Sander, H.W., Green, P.H.R., Hallett, M. and Latov, N. (2007) Immune Cross-Reactivity in Celiac Disease: Anti-Gliadin Antibodies Bind to Neuronal Synapsin I. The Journal of Immunology, 178, 6590-6595. http://www.jimmunol.org/content/178/10/6590.long http://dx.doi.org/10.4049/jimmunol.178.10.6590

[31] Young, K.A., Liu, Y., Gobrogge, K.L., Wang, H. and Wang, Z. (2014) Oxytocin Reverses Amphetamine-Induced Deficits in Social Bonding: Evidence for an Interaction with Nucleus Accumbens Dopamine. The Journal of Neuroscience, 34, 8499-8506. http://www.jneurosci.org/content/34/25/8499.long http://dx.doi.org/10.1523/JNEUROSCI.4275-13.2014

[32] Verna, R. (2013) The History and Science of Chocolate. Malaysian Journal Pathology, 35, 111-121. http://www.mjpath.org.my/2013.2/history-and-science-of-chocolate.pdf

[33] Oliveira, I.S. (2006) A Gênese Do Culto Cristão: Aspectossociais, religiosos e culturaisqueinfluenciaram e contribuíramnaformação do cultocristão. Escola Superior de Teologia, São Leopoldo. http://www3.est.edu.br/biblioteca/btd/Textos/Mest Prof/oliveira is tmp19.pdf

[34] Irsfeld, M., Spadafore, M. and Prüß, B.M. (2013) $\beta$-Phenylethylamine, a Small Molecule with a Large Impact. National Institutes of Health Public Access, 4, 4409.

https://www.activepharmaceutica.com.br/fileuploader/download/download/?d=1\&file=custom\%2Fupload\%2FFile-139 2733760.pdf

[35] Knakievicz, T. (2014). Empathy, Perception and Intelligence. Interparadigmas, 2, 103-121. http://www.interparadigmas.org.br/wp-content/uploads/2015/06/Interparadigmas-E-EN.pdf

[36] Rubí, B., Ljubicic, S., Pournourmohammadi, S., Carobbio, S., Armanet, M., Bartley, C. and Maechler, P. (2005) Dopamine D2-Like Receptors Are Expressed in Pancreatic Beta Cells and Mediate Inhibition of Insulin Secretion. The Journal of Biological Chemistry, 280, 36824-36832. http://www.jbc.org/content/280/44/36824.long http://dx.doi.org/10.1074/jbc.M505560200

[37] Fox, G.R., Kaplan, J., Damasio, H. and Damasio, A. (2015) Neural Correlates of Gratitude. Frontiers in Psychology, 6, 1-11. http://www.ncbi.nlm.nih.gov/pmc/articles/PMC4588123/pdf/fpsyg-06-01491.pdf http://dx.doi.org/10.3389/fpsyg.2015.01491

[38] Lim, C. and Putnam, D. (2010) Religion, Social Networks, and Life Satisfaction. American Sociological Review, 75 914-933. http://wcfia.harvard.edu/files/wcfia/files/rputnam_religion_social_networks.pdf http://dx.doi.org/10.1177/0003122410386686 
[39] Gikovate, F. (1987) Vício dos vícios: Um estudosobre a Vaidadehumana. MG Editores Associados, São Paulo, 64. http://flaviogikovate.com.br/preview_produtos/vicio_dos_vicios.pdf

[40] Wauke, A.P. (2005) Teática da Antecipação das Recins. Conscientia, 9, 113-110.

[41] Nietzsche, F.W. (2009) Genealogia da moral: Umapolêmica (Genealogy of Morals: A Controversy). Tradução Paulo César de Souza, Companhia das Letras, São Paulo. http://www.companhiadasletras.com.br/trechos/80134.pdf

[42] Kehl, M.R. (2004) Ressentimento. Coleção Clínica Psicanalítica. Casa do Psicólogo, São Paulo.

[43] White, M. (2000) Isaac Newton: O últimofeiticeiro (Isaac Newton: The Last Sorcerer). Tradução de Maria Beatriz Medina, Record, Rio de Janeiro.

[44] Henig, R.M. (2001) O Monge no Jardim. O Gênioesquecido e redescoberto de Gregor Mendel, o pai da Genética (The Monk in the Garden: The Lost and Found Genius of Gregor Mendel). Tradução de Ronaldo Sérgio de Biasi, Rocco, Rio de Janeiro.

[45] White, M. (2009) Galileu Anticristo: Uma biografia (Galileo Antichrist). Tradução Julián Fuks, Record, Rio de Janeiro.

[46] Gomes, F.G., Ceitlin, L.H., Hauck, S. and Terra, L. (2008) A relação entre osmecanismos de defesa e a qualidade da aliançaterapêuticaempsicoterapia de orientaçãoanalítica. Revista de Psiquiatria, 30, 109-114. http://www.scielo.br/pdf/rprs/v30n2/v30n2a06.pdf

[47] Silveira, L. (2013) Contratoem Processos de Aprendizagem e Desenvolvimento de Pessoas. Revista da SBDG, 6, 1019.

[48] Schein, E. (2009) Ajuda—A relaçãoessencial (Helping: How of Offer, Give, and Receive Help). Saraiva, São Paulo.

[49] Lopes, A. (2015) Senso de Dignidade Cosmoética. In Enciclopédia da Conscienciologia. Foz do Iguaçu: Associação Internacional do Centro de Altos Estudos da Conscienciologia (CEAEC) e Associação Internacional Editares (On Line). http://www.tertuliaconscienciologia.org/index.php?option=com_docman\&task=cat_view\&gid=14\&limit=20\&limitstar $\underline{\mathrm{t}=0 \text { \&order}=\text { date\&dir=ASC\&Itemid }=13}$

[50] Hicks, D. (2013) Dignidade: O Papelquedesempenhana Resolução de Conflitos (Dignity: The Essential Role It Plays in Resolving Conflict); tradutora. Fernanda Barrão Lisboa, Bizâncio.

[51] Villa, F. (2008) Primeiratransferência: Afastar a sugestão do somático. Ágora: Estudosem Teoria Psicanalítica, 11, 333-347. http://www.scielo.br/scielo.php?script=sci_arttext\&pid=S1516-14982008000200011

[52] Storr, A. (2012) A Agressividade Humana (Human Aggression). Tradução Cleci Leão, Benvirá, São Paulo. 